\section{MARKET-LED}

A few general points: the parties can select the law applicable to the substance of the dispute or other considerations agreed by the parties (for example, ex aqueo et bono); unless otherwise agreed the award must state its reasons; the ability to correct or clarify the award is strengthened.

All in all, the Act is well prepared having been the subject of considerable consultation and being market-led to preserve and enhance the attractiveness of this jurisdiction. It provides a platform for arbitrators to differentiate arbitrations from court proceedings and gives the parties (subject to the Act's mandatory provisions) a wide element of choice to agree how their arbitrations are to be conducted.

It will be interesting to see how users cope with the extensive freedom now offered. Institutional bodies will amend (or have amended) their rules. Ad hoc appointers may not manage to take advantage of the possibilities till arbitration arises. Experience on these matters will provide a guide to later reforms. (1)

Paul R Ellington

Cameron McKenna

\title{
International Trade
}

\section{Slipping up on bananas?}

$\mathrm{T}$ he completion of the EU's internal market necessitated the unification of diverse national policies on banana imports into one policy; this came into force in July 1993. In the establishment of the trading system, among the various factors to be reconciled were the Lomé Convention's banana protocol, which provided for traditional Community imports from the $\mathrm{ACP}$ and the interests of Latin-American countries for whom banana exports were of major economic importance. In this reconciliation of interests, the need to make the regulation consistent with international trade law also had to be considered. The new regime was applauded by ACP producers as it allowed for the continuation of their traditional exports to the Community. However, Latin-American producers were very critical of the regime and a complaint was made to the GATT (General Agreement on Tariffs and Trade) yet the reports were not adopted. A further complaint was made by Ecuador, Guatemala, Honduras, Mexico and the US to the World Trade Organisation (WTO) in 1996.

\section{COMMUNITY IN BREACH}

In April 1997 the final report of the WTO panel concluded that the Community's import regime for bananas was inconsistent with various provisions of the GATT, the Licensing Agreement and the General Agreement on Trading Services (GATS). The Community's notification of an appeal against this report sought to challenge each of the specific findings against the Community's

\section{by Dr Joseph McMahon}

import regime and, more importantly, the interpretation of the scope and coverage of the waiver granted to the Lomé Convention and the obligations of the Community under that Convention. The Community argued that the waiver allowed for preferential treatment to be accorded to products, including bananas, originating in the ACP states, as required by the provisions of the Convention. The panel concluded that the Community had no obligation under the Convention to allocate tariff quota shares to the ACP in excess of their best-ever exports to the Community as they had under the banana regulation. By doing so, the Community had acted in breach of art. 13 and this breach was not covered by the waiver.

\section{FUTURE AMENDMENT}

The existing waiver expires in 2000 by which time the Convention will have been renegotiated. The Commission has offered a menu of six potential trade arrangements, none of which are problem-free. The ACP clearly would like the existing arrangements to continue. However, the Commission believes that some changes in those arrangements are necessary, not least to ensure their greater conformity with WTO rules. How is this difference to be resolved? Moreover could the relationship - and some ACP states survive the amendment of the banana regulation in line with the findings of the panel?

The most important factor in this resolution is the new atmosphere engendered by the WTO which makes it evident that the new Convention will be more consistent with those rules than previous Conventions. In terms of consistency, some adaptation of the existing agreement is necessary. The minimum requirement would be to introduce some element of reciprocity, but not all ACP countrics are in a position to offer reciprocal concessions. If reciprocity is offered and free tracle areas are contemplated, such areas must be consistent with art. 14. This too is problematic.

As for the more immediate problem facing the Community, the amendment of the banana regulation, one argument would be that if, after over 20 years of co-operation, ACP banana exports remain uncompetitive on the Community market, perhaps the time has come to end that co-operation. The economic cost to various ACP states of this option is too high to be realistically contemplated. If the appellate body confirms the panel report, the subsequent amendment of the banana regulation will need to consider this and the renegotiation of the current Lomé Convention will have to provide greater assistance to the affected ACP states. Otherwise, the Community will continue to slip up on bananas.

\section{Dr Joseph A McMahon \\ The Queen's University of Belfast}

